\title{
Expression of arginase $I$ and inducible nitric oxide synthase in the peripheral blood and lymph nodes of HIV-positive patients
}

\author{
NAICHUN ZHANG ${ }^{1,2}$, JIANNING DENG ${ }^{3}$, FENGYAO WU ${ }^{3}$, XIANGCHAN LU ${ }^{3}$, LEI HUANG ${ }^{1}$ and MIN ZHAO ${ }^{1,2}$ \\ ${ }^{1}$ Treatment and Research Center for Infectious Diseases, The 302 Hospital of PLA, Beijing 100039; \\ ${ }^{2}$ Health Science Center, Peking University, Beijing 100191; ${ }^{3}$ AIDS Department, \\ The 4th People's Hospital of Nanning/Guangxi AIDS Clinical Treatment Center, Nanning, Guangxi 530023, P.R. China
}

Received January 14, 2015; Accepted October 21, 2015

DOI: $10.3892 / \mathrm{mmr} .2015 .4601$

\begin{abstract}
Arginase I (Arg I) and inducible nitric oxide synthase (iNOS) are important in regulating immune functions through their metabolites. Previous studies have revealed that the expression of Arg I is increased and the expression of iNOS is reduced in the serum and peripheral blood mononuclear cells of human immunodeficiency virus (HIV)-infected patients. As one of the most important immune organs and HIV replication sites, whether similar changes are present in the lymph nodes following HIV infection remains to be elucidated. To investigate this, the present study collected lymph node and blood specimens from $52 \mathrm{HIV}$-infected patients to measure the expression levels of Arg I and iNOS by immunohistochemistry and fluoresence-based flow cytometry. Compared with control subjects without HIV infection, the patients with HIV had significantly higher expression levels of Arg I in the lymph nodes and higher frequencies of $\mathrm{Arg} \mathrm{I}^{+} \mathrm{CD}^{+} \mathrm{T}$ cells and $\mathrm{CD} 8^{+} \mathrm{T}$ cells in the blood and lymph nodes, and these results were contrary the those of iNOS in the corresponding compartments. The expression levels of Arg I in the lymph nodes and blood were negatively associated with peripheral $\mathrm{CD} 4^{+} \mathrm{T}$ cell count and positively associated with viral load. However, the expression levels of iNOS in the lymph nodes and blood were positively associated with peripheral $\mathrm{CD} 4^{+} \mathrm{T}$ cell count and negatively associated with viral load. These results showed that alterations in the expression levels of Arg I and iNOS in the peripheral T cells and peripheral nodes of HIV infected patients are associated with disease progression in these patients. These results indicate a potential to therapeutic strategy for delaying disease progression through regulating
\end{abstract}

Correspondence to: Dr Min Zhao or Mr. Lei Huang, Treatment and Research Center for Infectious Diseases, The 302 Hospital of PLA, 100 West Fourth Ring Middle Road, Beijing 100039, P.R. China

E-mail: drzhaomin@sina.com

E-mail: huangleiwa@sina.com

Key words: human immunodeficiency virus, arginase I, inducible nitric oxide synthase, peripheral superficial lymph nodes and manipulating the expression levels of Arg I and iNOS in patients infected with HIV.

\section{Introduction}

At present, the trends in human immunodeficiency virus (HIV) infection remain at a high level worldwide (1). The treatment of HIV/acquired immune deficiency syndrome (AIDS) has been challenging, although highly active antiretroviral therapy (HAART) has significantly reduced the number of new cases of HIV infection and improved the prognosis of patients with HIV/AIDS (2). During previous decades, there have been significant advances in understanding the pathogenesis of HIV/AIDS, however certain aspects remain to be elucidated, including the functional changes in immune organs, for example the lymph nodes, following HIV infection.

The damage caused by HIV infection is gradual and multi-staged, and ends in AIDS (3). Chronic HIV infection may progressively compromise immune functions. The loss of peripheral $\mathrm{CD}^{+} \mathrm{T}$ lymphocytes due to continuous and severe injury has been a marker of AIDS progression and a major cause of immune dysfunction in HIV/AIDS (4). However, HIV infection-induced chronic inflammation and the reduction in the number of $\mathrm{CD}^{+} \mathrm{T}$ lymphocytes does not fully explain the immune dysfunction, which occurs in the progression of HIV/AIDS.

Previous studies have shown that the metabolism of L-arginine is one of the important mechanisms underlying the regulation of immune responses $(5,6)$. L-arginine is a substrate of arginase (Arg), including Arg I and II, and nitric oxide synthase (NOS), including NOS1, 2 and 3). Arg I and II hydrolyzes L-arginine into L-ornithine and urea, and L-ornithine is further metabolized into polyamines, which are involved in the proliferation and differentiation of cells (7). NOS catalyzes the conversion of $\mathrm{L}$-arginine into citrulline and nitric oxide (NO), and NO is an important effector and regulator of the immune system $(8,9)$. Arg I is released from immune cells, including polymorphonuclear neutrophils, during inflammation, and is also involved in the inflammatory response (10). NOS2, or inducible NOS (iNOS) is expressed in a variety of immune cells (11). Studies have reported that Arg I regulates the bioavailability of L-arginine, which is involved in certain immune-associated pathological processes, including 
inflammation-triggered immune dysfunction, immune evasion of cancer cells, fibrosis, immunosuppression and immune responses to infectious agents $(5,11,12)$. As a competitor to Arg I, iNOS hydrolyzes L-arginine into NO, which is important in destroying parasites, bacteria, viruses and cancer cells, as well as in vascular dilation (13-15).

Previous studies have revealed that the expression of Arg I is increased $(16,17)$ and the expression of iNOS is reduced (18) in the serum and peripheral blood mononuclear cells (PBMCs) of patients with HIV. However, the expression levels of Arg I and iNOS in the peripheral lymph nodes (LNs) of HIV-infected patients remains to be fully elucidated. In the present study, the expression levels of Arg I and iNOS in peripheral LNs and peripheral $\mathrm{T}$ cells were investigated, with the aim of elucidating the roles of Arg I and iNOS in the progression of HIV/AIDS.

\section{Materials and methods}

Characteristics of subjects. A total of 52 patients (mean age, 40.73 \pm 11.99 years; range: $23-65$ years; males, 43; females, 9; male-to-female ratio, 4.78:1) with HIV infection and enlarged peripheral LNs were recruited from the 302 Hospital of PLA (Beijing, China) and the 4th People's Hospital of Nanning (Nanning, China) between July 2009 and October 2014. Informed consent was obtained prior to surgical resection of the LNs, and the study was approved by the Ethics Committees of the 302 Hospital of PLA (Beijing, China) and the 4th People's Hospital of Nanning (Nanning, China). LNs were routinely collected during surgery from the neck $(n=27)$, armpit $(n=20)$ and groin $(n=5)$, and were processed for further examination. At the same time, $10 \mathrm{ml}$ peripheral blood was collected from the patient and control groups. HIV/AIDS was diagnosed according to the Guidelines for the Use of Antiretroviral Agents in HIV-1-infected Adults and Adolescents (USDHHS 2013) (19), and these patients were divided into an asymptomatic group $(n=19)$ and an AIDS group $(n=33)$. In addition, peripheral superficial biopsies of the LNs were collected from the neck and armpit of 13 subjects without HIV infection, recruited from the 302 Hospital of PLA, and were processed for pathological examination by two experienced pathologists. Exclusion criteria included the presence of cancer, infection and autoimmune diseases, and the presence of reactive hyperplasia was confirmed in those subjects who then served as controls. In addition, peripheral blood was collected from 20 healthy control subjects.

Absolute $\mathrm{CD}^{+} \mathrm{T}$ cell count. The peripheral blood CD4+T-cell counts were determined using the Multitest Imk Lymphocyte kit (cat. no. 340503; BD Biosciences, San Jose, CA, USA) and Trucount tubes (cat. no. 340504; BD Biosciences). $50 \mu \mathrm{l}$ whole blood was collected and incubated with $10 \mu \mathrm{l}$ antibodies for $20 \mathrm{~min}$ at room temperature. 1X BD Multitest IMK kit lysis solution was subsequently added to the tubes and after $15 \mathrm{~min}$ of incubation at room temperature, $\mathrm{CD} 4{ }^{+} \mathrm{T}$ cells were counted using flow cytometry (FACSCanto II; BD Biosciences).

Detection of viral load. Blood was processed within 2-4 h post-collection by centrifugation for $10 \mathrm{~min}$ at $1,100 \mathrm{x} \mathrm{g}$ for plasma separation, followed by HIV RNA extraction by using a Roche Cobas AmpliPrep/Cobas TaqMan automatic analysis system (Roche Diagnostics; Basel, Switzerland, USA). The viral load was quantitatively measured using a Roche Cobas AmpliPrep/Cobas TaqMan HIV-1 test kit (version 2.0; Roche Diagnostics) according to the manufacturer's instruction.

Separation of mononuclear cells from LNs. The LNs were minced and filtered through a 100 mesh filter (pore size, $150 \mu \mathrm{m}$; xbs-100; Shanghai 3bio, Shanghai, China), and the filtrate was retained and layered onto Ficoll-Paque ${ }^{\mathrm{TM}}$ PLUS (cat. no. 17-1440-02; GE Healthcare, Little Chalfont, UK) and centrifuged at $800 \mathrm{x} \mathrm{g}$ for $15 \mathrm{~min}$ at $20^{\circ} \mathrm{C}$ to obtain mononuclear cells, which included lymphocytes $(20,21)$.

Detection of the expression levels of Arg I and iNOS using streptomycin avidin-biotin-peroxidase complex immunohistochemical analysis. The LNs were collected, fixed in 4\% paraformaldehyde (Beijing Chemical Works, Beijing, China), embedded in paraffin (Leica Biosystems, Nussloch, Germany) and sectioned $(4 \mu \mathrm{m})$. Briefly, the slides were washed in xylene (ZSGB-BIO, Beijing, China) to remove the paraffin, rehydrated through serial dilutions of alcohol (Beijing Chemical Works), followed by washing with phosphate-buffered saline (PBS; pH 7.2; ZLI-9062, ZSGB-BIO). Treated slides were then placed in a 0.01-mol/1 citrate buffer ( $\mathrm{pH}$ 6.0; ZSGB-BIO) and heated in a microwave oven for $15 \mathrm{~min}$ for retrieval of antigens, treated with $1.5 \% \mathrm{H}_{2} \mathrm{O}_{2}$ (Beijing Chemical Works) in methanol (Beijing Chemical Works) to inactivate endogenous peroxidase and treated with fetal bovine serum (Invitrogen; Thermo Fisher Scientific, Waltham, MA, USA) to block non-specific binding. The sections were then incubated overnight at $4^{\circ} \mathrm{C}$ with anti-hArginase1 antibody [cat. no. IC8026P; monoclonal mouse immunoglobulin (Ig) G2B; clone 658922; 1:350 dilution; R\&D Systems, Minneapolis, MN, USA], anti-iNOS antibody (cat. no. ab15323; rabbit polyclonal; 1:80 dilution; Abcam, Cambridge, UK) and washed three times with PBS, followed by incubation with horseradish peroxidase (HRP)-conjugated secondary antibody (cat no. D39-110; Polink-2 Plus HRP Rabbit for DAB Bulk kit; or cat no. D37-110; Polink-2 Plus HRP DAB Mouse Bulk kit; Golden Bridge International, Bothell, WA, USA) for $15 \mathrm{~min}$ at $37^{\circ} \mathrm{C}$. The sections were then incubated with 3,3-diaminobenzidine (ZSGB-BIO) to visualize the expression of Arg I and iNOS. Positive cells contained brown granules. As a negative control for the LNs from HIV-infected patients, phosphate-buffered saline was used in place of the primary antibody. LN sections from subjects without HIV were treated with primary antibody also served as a control.

Determination and image capture. The specimens were evaluated semi-quantitatively by two pathologists in a blinded-manner (22). The frequencies of positive cells to total cells at x200 magnification were scored as follows: $1, \leq 25 \% ; 2$, $26-50 \% ; 3,>51 \%$. The staining intensity above the background level was scored as follows: 0, no staining; 1, light yellow; 2, yellow-brown; 3 , brown. These scores served as measures of target protein expression. The final score was the product of the above two scores: 0 , negative $(-)$; $1-2$, weakly positive $(+)$; $3-4$, positive $(++)$; 6-9, strongly positive $(+++)$. Slides were mounted with gum for examination and captured using an Olympus BX51 microscope (Olympus Corp., Tokyo, Japan) and a Nikon Digital Camera System (80i; Nikon Corp., Tokyo, 
Japan) for study comparison. For this evaluation, five fields were randomly selected per section (magnification, x200).

Detection of the expression levels of Arg I and iNOS using flow cytometry. The mononuclear cells from the peripheral blood or LNs were added to three tubes $\left(2-5 \times 10^{5}\right.$ cells/tube), and were incubated with anti-CD3-fluorescein isothiocyanate (cat. no.349201; monoclonal mouse IgG1; clone SK7; BD Biosciences) and anti-CD8-peridinin chlorophyll protein (cat. no. 347314; monoclonal mouse IgG1; clone SK1; BD Biosciences) and permeabilized using a Cytofix/Cytoperm Fixation/Permeabilization kit (BD Biosciences). Subsequently, the three tubes (Arg, iNOS and isotype control) were divided into three groups and either anti-hArginase1-phycoerythrin (cat. no. IC8026P; monoclonal mouse IgG2B; clone 658922; R\&D Systems), anti-iNOS antibody (cat. no. ab15323; rabbit polyclonal; Abcam) or isotype control antibody (cat. no. IC0041P; monoclonal mouse IgG2B; clone 133303; R\&D Systems) was added to one tube containing peripheral blood mononuclear cells and one tube containing LN mononuclear cells. 1XBD Perm/Wash ${ }^{\mathrm{TM}}$ Buffer from the kit was used for washing. The cells in the iNOS group were incubated with goat anti-rabbit IgG-allophycocyanin (cat. no. ab130805; polyclonal; Abcam) for $15 \mathrm{~min}$ at $20^{\circ} \mathrm{C}$ and fixed in $1 \%$ paraformaldehyde for $24 \mathrm{~h}$. Flow cytometry was performed within $24 \mathrm{~h}$ using a FACSCanto II flow cytometer (BD Biosciences). FlowJo software (version 7.6.1; FlowJo LLC, Ashland, OR, Canada) was used to analyze the data. The lymphocytes were gated based on forward scatter/side scatter, which were further separated into $\mathrm{CD}^{+} \mathrm{T}$ cells $\left(\mathrm{CD}^{+} / \mathrm{CD}^{+}\right)$and $\mathrm{CD}^{+} \mathrm{T}$ cells $\left(\mathrm{CD}^{+} / \mathrm{CD}^{-}\right)$, and the expression levels of Arg I and iNOS were analyzed.

Statistical analysis. Statistical analysis was performed using SPSS version 17.0 (SPSS, Inc., Chicago, IL, USA). Continuous variables were compared using analysis of variance (ANOVA) and one-way ANOVA was used to evaluate the differences among groups. Non-continuous variables were compared using a Mann-Whitney U test between two groups and Kruskal-Wallis H non-parametric test among groups. Correlation was evaluated using Pearson's or Spearman's correlation analysis. $\mathrm{P}<0.05$ was considered to indicate a statistically significant difference.

\section{Results}

Expression levels of Arg I and iNOS in the LNs of patients with HIVIAIDS. In order to determine changes in the expression levels of Arg I and iNOS in LNs following HIV infection, the present study firstly evaluated the expression levels of Arg I and iNOS in peripheral LNs in situ using immunohistochemistry. The results showed that Arg I was predominantly expressed in the cytoplasm, and the levels of expression varied among the groups, between negative to strongly positive. In the control group (Fig. 1A), the expression of Arg I was most weakly positive or positive, whereas the expression levels of Arg I in the patient groups (Fig. 1B and 1C), were almost positive or strongly positive. By contrast, the expression of iNOS exhibited the opposite trend to the changes in the expression of Arg I, with the expression of iNOS being positive in the control group (Fig. 1D), and positive, weakly positive or negative in the patient groups (Fig. 1E and F). Taken together, the results of the immunohistochemical analyses showed that, in the patient groups, the expression levels of Arg I were significantly higher, compared with the control group $(\mathrm{P}<0.01$; Fig. $1 \mathrm{G})$, whereas the expression levels of iNOS were significantly lower, compared with the control group $(\mathrm{P}<0.05$; Fig. $1 \mathrm{H})$. No significant differences were observed between the asymptomatic and AIDS groups $(\mathrm{P}>0.05)$.

Expression levels of Arg I and iNOS in the peripheral T cells of patients with HIVIAIDS. Subsequently, the present study detected the frequencies of $\mathrm{Arg}^{+}$and $\mathrm{iNOS}^{+} \mathrm{CD}^{+} \mathrm{T}$ cells and $\mathrm{CD}^{+} \mathrm{T}$ cells, which were isolated from the peripheral blood samples or LN tissues of the asymptomatic patients, symptomatic patients with AIDS and controls. Flow cytometry was performed to further assess the changes in the expression levels of Arg I and iNOS in the T lymphocyte subsets. In the asymptomatic and symptomatic AIDS groups, the frequencies of $\mathrm{CD}^{+} \mathrm{T}$ cells positive for Arg I in the peripheral blood were significantly higher, compared with the control $(\mathrm{P}<0.05)$, and the frequencies of $\mathrm{CD} 4^{+} \mathrm{T}$ cells positive for iNOS in the peripheral blood were significantly lower, compared with the control $(\mathrm{P}<0.05)$ (Fig. 2). In addition, the frequencies of $\mathrm{CD}^{+}$ $\mathrm{T}$ cells positive for Arg I in the peripheral blood were significantly higher, compared with the control $(\mathrm{P}<0.05)$, and those positive for iNOS in the peripheral blood were significantly lower, compared with the control $(\mathrm{P}<0.05)$ (Fig. 3). However, the frequencies were similar between these patient groups $(\mathrm{P}>0.05)$. Analogous results were obtained from peripheral LNs. In the two patient groups, the frequencies of $\mathrm{CD}^{+} \mathrm{T}$ cells positive for Arg I in the peripheral LNs were significantly higher $(\mathrm{P}<0.05)$, and those positive for iNOS were significantly lower $(\mathrm{P}<0.05)$, compared with the controls (Fig. 4). The frequencies of $\mathrm{CD}^{+} \mathrm{T}$ positive for Arg I in the peripheral LNs cells were significantly higher $(\mathrm{P}<0.05)$, and those positive for iNOS were significantly lower $(\mathrm{P}<0.05)$, compared with the control (Fig. 5). The frequencies did not differ significantly among the patient groups $(\mathrm{P}>0.05)$.

Correlation between the expression levels of Arg I and $i N O S$, and $\mathrm{CD}^{+} \mathrm{T}$ cell counts. The $\mathrm{CD} 4^{+} \mathrm{T}$ cell count is an important clinical indicator of the progression of AIDS (23). To investigate the effects of Arg I and iNOS on the progression of AIDS, the associations between the peripheral blood $\mathrm{CD}^{+} \mathrm{T}$ cell count and the frequencies of $\mathrm{CD}^{+} \mathrm{T}$ cells and $\mathrm{CD}^{+} \mathrm{T}$ cells positive for Arg I and iNOS were examined in the peripheral blood and peripheral LNs. The protein expression levels of Arg I and iNOS in the peripheral LNs were also evaluated. As shown in Fig. 6, the peripheral $\mathrm{CD}^{+}{ }^{+} \mathrm{T}$ cell count was negatively associated with the frequencies of $\mathrm{CD}^{+}$ $\mathrm{T}$ cells and $\mathrm{CD}^{+} \mathrm{T}$ cells positive for Arg I in the peripheral blood ( $\mathrm{r}=-0.393 ; \mathrm{P}<0.01$ and $\mathrm{r}=-0.527 ; \mathrm{P}<0.01$; respectively) and peripheral LNs $(\mathrm{r}=-0.326 ; \mathrm{P}<0.01$; and $\mathrm{r}=-0.292 ; \mathrm{P}=0.036$, respectively). However, the peripheral $\mathrm{CD}^{+} \mathrm{T}$ cell count was positively associated with the frequencies of $\mathrm{iNOS}^{+} \mathrm{CD}^{+}$ $\mathrm{T}$ cells and $\mathrm{CD}^{+} \mathrm{T}$ cells in the peripheral blood $(\mathrm{r}=0.690$; $\mathrm{P}<0.01$ and $\mathrm{r}=0.604 ; \mathrm{P}<0.01$; respectively) and peripheral LNs $(r=0.596 ; \mathrm{P}<0.01$ and $\mathrm{r}=0.611 ; \mathrm{P}<0.01$, respectively; Fig. 6).

Correlation between the expression levels of Arg I and iNOS, and viral load. Viral load is another important indicator used 


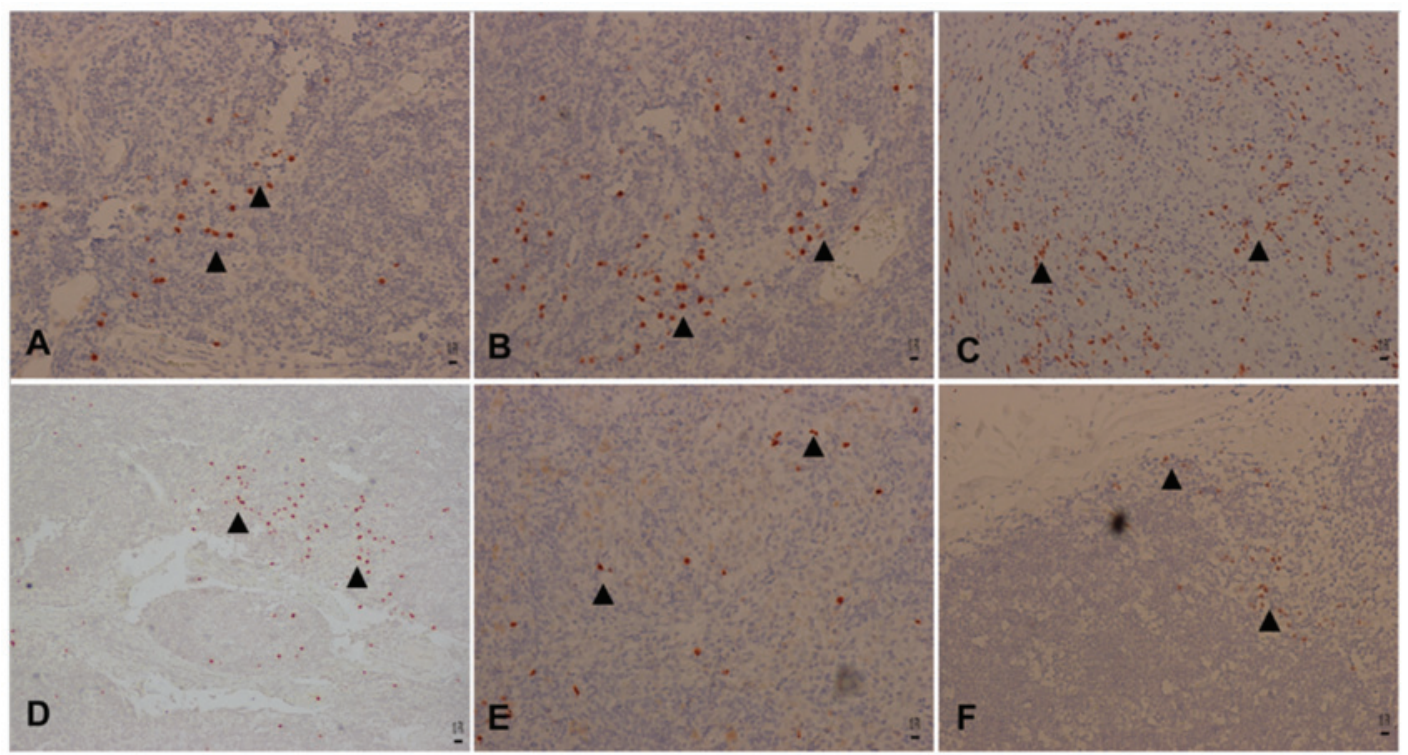

G

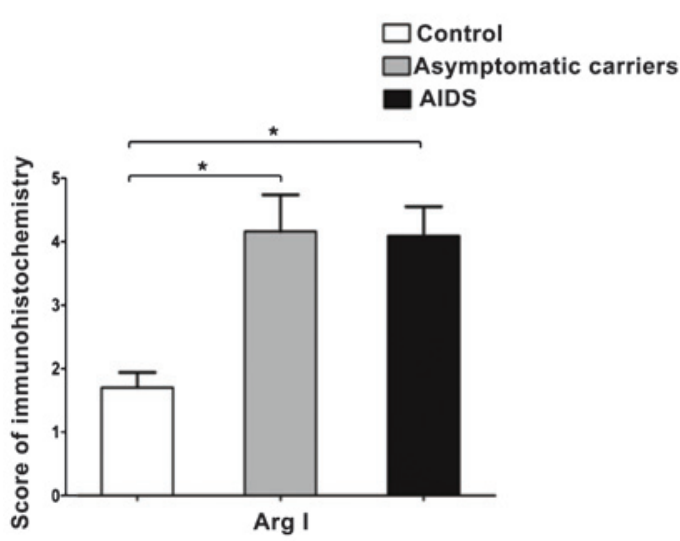

$\mathbf{H}$

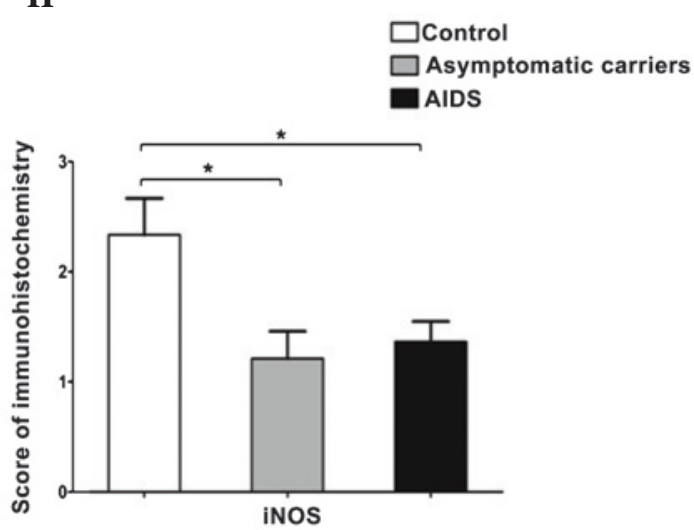

Figure 1. Protein expression levels of Arg I and iNOS in the peripheral LNs. Expression of Arg I in the LNs was positive in the (A) control group and strongly positive in the (B) asymptomatic group and (C) symptomatic AIDS group. Expression of iNOS in the LNs was strongly positive in the (D) control group, and positive in the (E) asymptomatic group and (F) symptomatic AIDS group. Arrows indicate positive staining using the Polink-2 plus ${ }^{\circledR}$ Polymer HRP Detection system (magnification, x200). (G and H) Immunohistochemical scores for the expression levels of Arg I and iNOS in the superficial LNs of the control group, asymptomatic group and symptomatic AIDS group. Values are expressed as the mean standard \pm deviation from at least three experiments. ${ }^{*}<0.05$. Arg, arginase; iNOS, inducible nitric oxide synthase; LN, lymph node; AIDS, acquired immune deficiency syndrome.

to evaluate the severity of AIDS. Therefore, the present study also evaluated the association between the viral load and the frequencies of $\mathrm{CD}^{+} \mathrm{T}$ cells and $\mathrm{CD} 8^{+} \mathrm{T}$ cells positive for Arg I or iNOS in the peripheral blood and LNs. The association with the protein expression levels of Arg I and iNOS in the peripheral LNs were also examined. As shown in Fig. 7, viral load was positively associated with the frequencies of Arg I positive $\mathrm{CD}^{+} \mathrm{T}$ cells and $\mathrm{CD} 8^{+} \mathrm{T}$ cells in the peripheral blood $(\mathrm{r}=0.495 ; \mathrm{P}<0.01$ and $\mathrm{r}=0.307 ; \mathrm{P}=0.027$, respectively), peripheral LNs ( $\mathrm{r}=0.546 ; \mathrm{P}<0.01$ and $\mathrm{r}=0.458 ; \mathrm{P}<0.01$, respectively). However, the viral load was negatively associated with the frequencies of iNOS positive $\mathrm{CD}^{+} \mathrm{T}$ cells and $\mathrm{CD} 8^{+} \mathrm{T}$ cells in the peripheral blood $(r=-0.735 ; \mathrm{P}<0.01$ and $\mathrm{r}=-0.757 ; \mathrm{P}<0.01$, respectively), peripheral LNs $(\mathrm{r}=-0.778 ; \mathrm{P}<0.01$ and $\mathrm{r}=-0.670$; $\mathrm{P}<0.01$, respectively). In terms of protein expression levels, the peripheral $\mathrm{CD}^{+} \mathrm{T}$ cell count was negatively associated with the protein expression of Arg I ( $\mathrm{r}=-0.563$; $\mathrm{P}<0.01$; Fig. 8A) and the viral load was positively associated with the protein expression of Arg I in the LNs ( $\mathrm{r}=0.736$; $\mathrm{P}<0.01$; Fig. $8 \mathrm{~B}$ ).
Furthermore, the peripheral $\mathrm{CD}^{+} \mathrm{T}$ cell count was positively associated with the expression of iNOS $(r=0.394 ; \mathrm{P}<0.01$; Fig. 8C) in the LNs. The viral load as negatively associated with the protein expression of iNOS in the LNs $(r=-0.529$; $\mathrm{P}<0.01$; Fig. 8D).

\section{Discussion}

As one of the most important amino acids, L-arginine can exert a variety of biological effects. It is involved in the synthesis of proteins, urea, creatine and NO (24), and is metabolized in the human body via the 'Arg pathway' and 'iNOS pathway,' which differ in their effects on immune function.

As mentioned above, the expression of Arg I is increased $(16,17)$ and the expression of iNOS is reduced (18) in the serum and PBMCs of HIV-infected patients. LNs are important sites for the proliferation, differentiation and development of lymphocytes, and are crucial in the maintenance of normal immune function (25). Changes in the metabolism of 
A

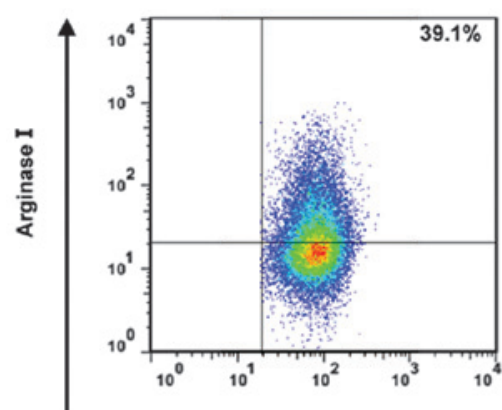

B

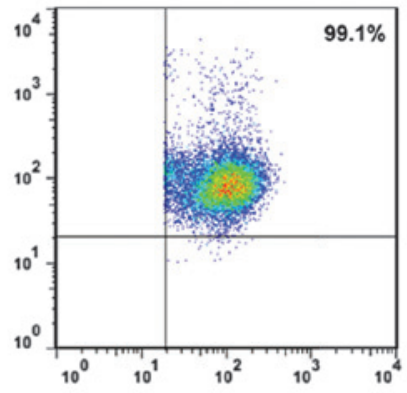

C

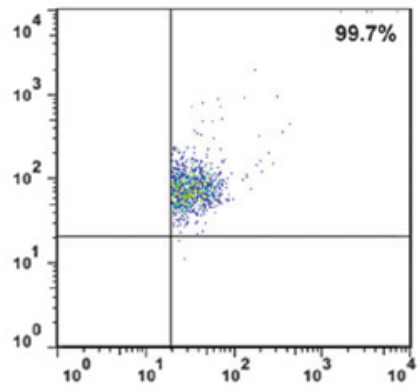

CD4+(CD3+CD8-)

D

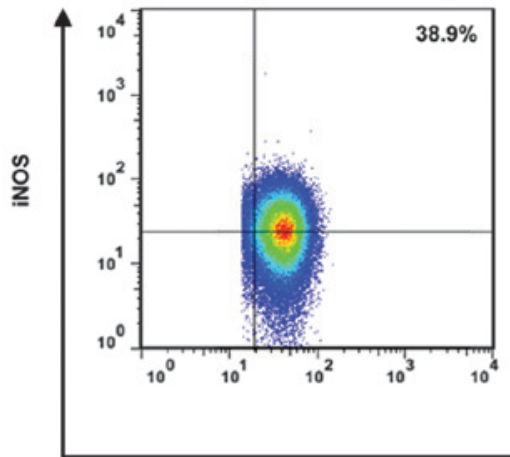

E

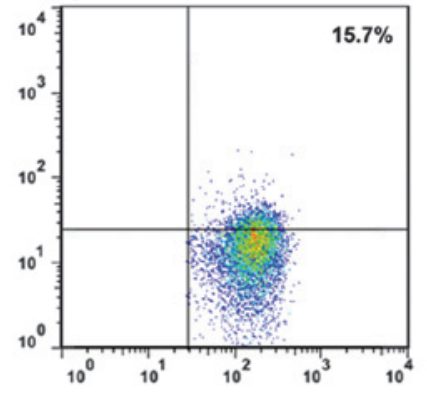

F

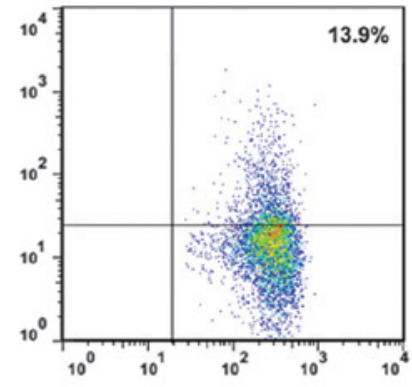

CD4+(CD3+CD8-)

G

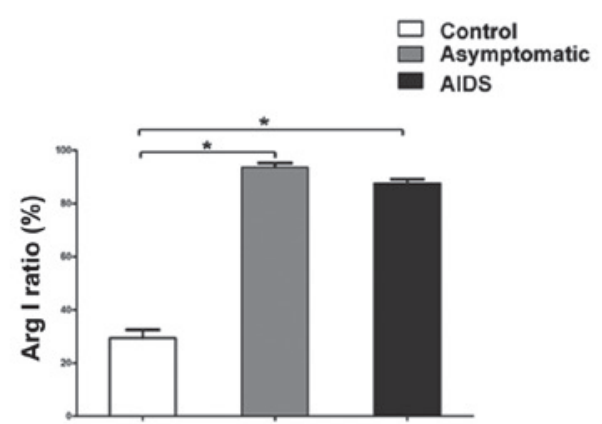

H

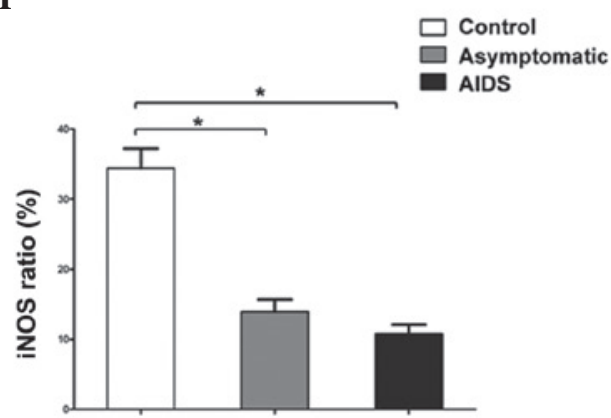

Figure 2. Flow cytometric analysis of the frequencies of $\mathrm{CD} 4^{+} \mathrm{T}$ cells positive for $\mathrm{Arg}$ I and iNOS in the peripheral blood. Compared with the (A) control group, the (B) asymptomatic group and (C) symptomatic AIDS group had a significantly higher frequency of peripheral CD4 ${ }^{+} \mathrm{T}$ cells positive for Arg I. Compared with the (D) control, the (E) asymptomatic group and (F) symptomatic AIDS group had a significantly lower frequency of peripheral CD4 ${ }^{+} \mathrm{T}$ cells positive for iNOS. Numbers represent the percentages of cells in the indicated boxes. $(\mathrm{G}$ and $\mathrm{H})$ Frequencies of peripheral $\mathrm{CD} 4^{+} \mathrm{T}$ cells positive for Arg I and iNOS. Values are expressed as the mean standard \pm deviation from at least three experiments. ${ }^{*}<0.05$. Arg, arginase; iNOS, inducible nitric oxide synthase; LN, lymph node; AIDS, acquired immune deficiency syndrome.

LNs by L-arginine remains to be fully elucidated in patients with HIV infection. Therefore, in the present study, immunohistochemistry and flow cytometry were used to detect the expression levels of Arg I and iNOS in peripheral T cells and LNs. The results showed that, compared with controls, asymptomatic and symptomatic HIV infected patients exhibited increased frequencies of Arg I positive CD4 ${ }^{+} \mathrm{T}$ cells and $\mathrm{CD}^{+} \mathrm{T}$ cells in the peripheral blood and LNs, and increased protein expression levels of Arg I in the LNs. In addition, the frequencies of Arg I positive $\mathrm{CD} 4^{+} \mathrm{T}$ cells and $\mathrm{CD} 8^{+} \mathrm{T}$ cells in the peripheral blood and LNs, and the protein expression levels of Arg I in the LNs were negatively associated with peripheral $\mathrm{CD}^{+} \mathrm{T}$ cell count and positively correlated with HIV load. By contrast, the frequencies of iNOS positive CD $4^{+}$ $\mathrm{T}$ cells and $\mathrm{CD}^{+} \mathrm{T}$ cells in the peripheral blood and LNs, and the protein expression levels of iNOS were decreased in the LNs of HIV-infected patients, compared with controls. Furthermore, the frequencies of iNOS positive CD $4^{+} \mathrm{T}$ cells and $\mathrm{CD}^{+} \mathrm{T}$ cells in the peripheral blood and LNs, and the protein expression levels of iNOS in the LNs were positively associated with peripheral $\mathrm{CD} 4^{+} \mathrm{T}$ cell count and negatively associated with HIV load. 
A

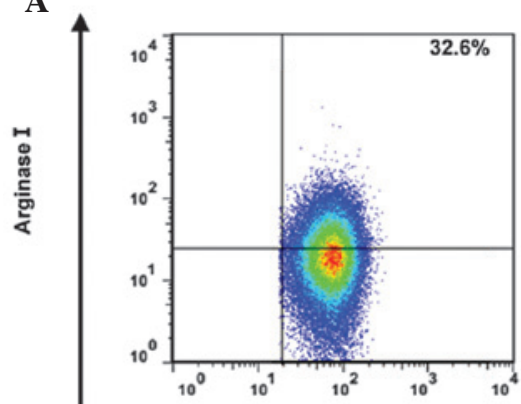

B

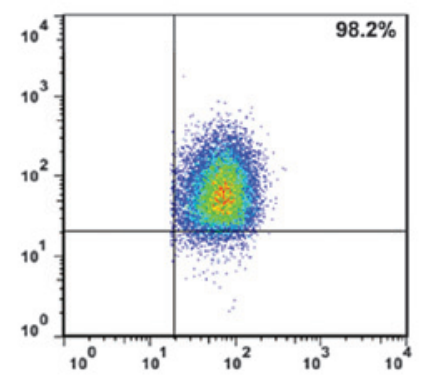

C

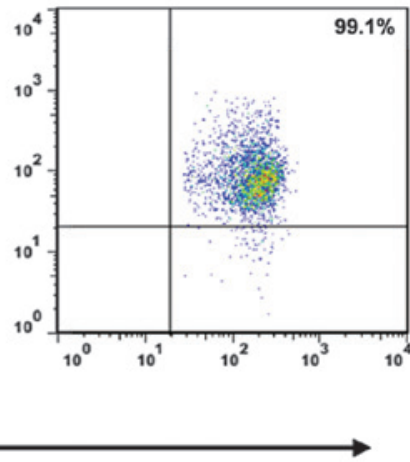

$\mathrm{CD} 8+(\mathrm{CD} 3+\mathrm{CD} 8+)$

D

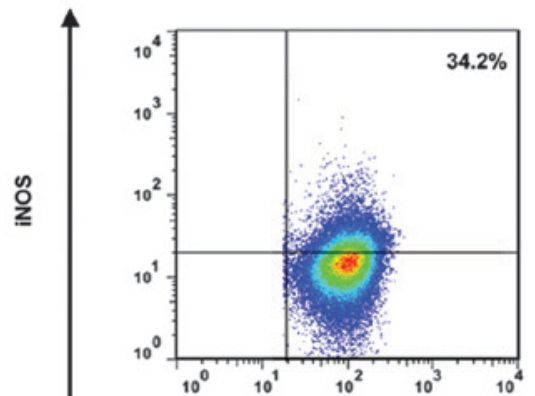

$\mathbf{E}$

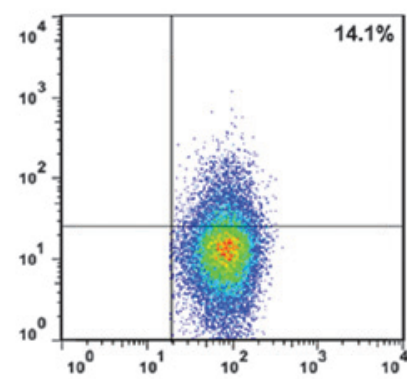

F

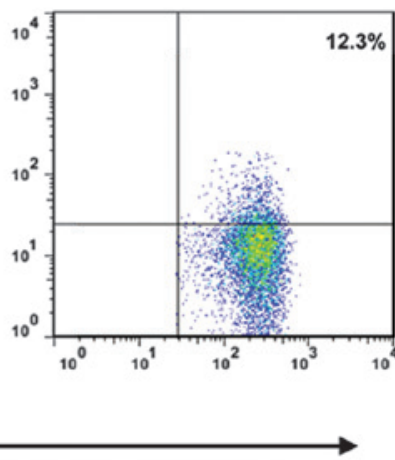

$\mathrm{CD} 8+(\mathrm{CD} 3+\mathrm{CD} 8+)$

G

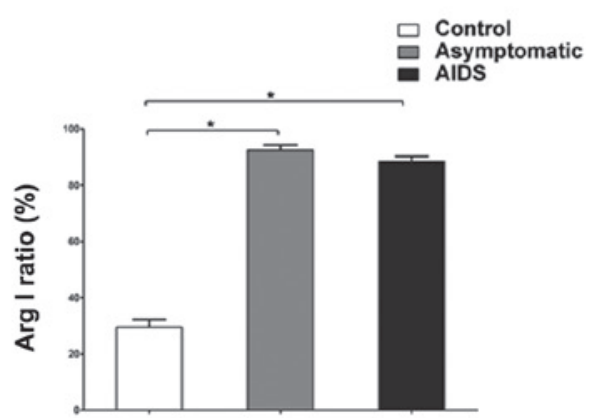

$\mathbf{H}$

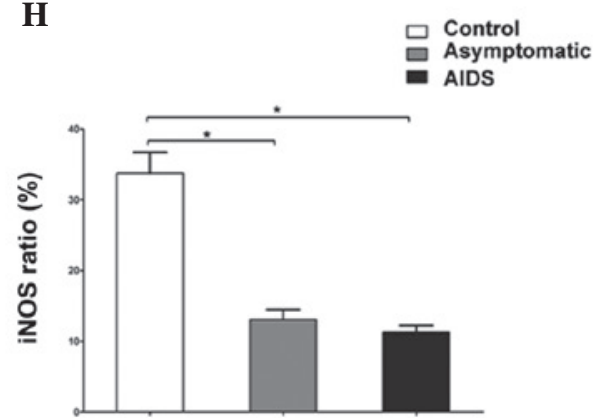

Figure 3. Flow cytometric analysis of the frequencies of CD8 $8^{+} \mathrm{T}$ cells positive for Arg I and iNOS in peripheral blood. Compared with the (A) control group, the (B) asymptomatic group and (C) symptomatic AIDS group had a significantly higher frequency of peripheral CD $8^{+} \mathrm{T}$ cells positive for Arg I. Compared with the (D) control, the (E) asymptomatic group and (F) symptomatic AIDS group had a significantly and a markedly lower frequencies of peripheral CD8 ${ }^{+} \mathrm{T}$ cells positive for Arg I and iNOS. Numbers represent the percentages of cells in the indicated boxes. $(\mathrm{G}$ and $\mathrm{H}$ ) Frequencies of peripheral CD8+T cells positive for Arg I and iNOS. Values are expressed as the mean standard \pm deviation from at least three experiments. " $\mathrm{P}<0.05$. Arg, arginase; iNOS, inducible nitric oxide synthase; LN, lymph node; AIDS, acquired immune deficiency syndrome.

In arginine-mediated metabolism, L-arginine is hydrolyzed into urea and ornithine, and ornithine is a precursor of polyamines, which are indispensable for the proliferation of cells and parasites (5,26-28). At least two subtypes of arginase have been identified in mammals: Cytoplasmic Arg I and mitochondrial Arg II (29). These are involved in the same reaction (30), although Arg I is more important in the urea cycle of the liver. In addition to its role in L-arginine metabolism, Arg is important for immune system function $(31,32)$ as it can inhibit NO synthesis, induce fibrosis and tissue regeneration $(33,34)$. Arg is also involved in multiple inflammatory diseases, and is essential for normal $\mathrm{T}$ cell function $(6,35,36)$.

In myeloid cells, Arg I downregulates CD3ל-chain expression, and inhibits the expression of cell cycle regulatory protein D3 and cell cycle regulatory protein-dependent kinase 4, leading to the inhibition of $\mathrm{T}$ cell activation and subsequent suppression of the immune function of T cells $(37,38)$. This mechanism is important in the immunosuppression of certain inflammation-associated conditions. 
A

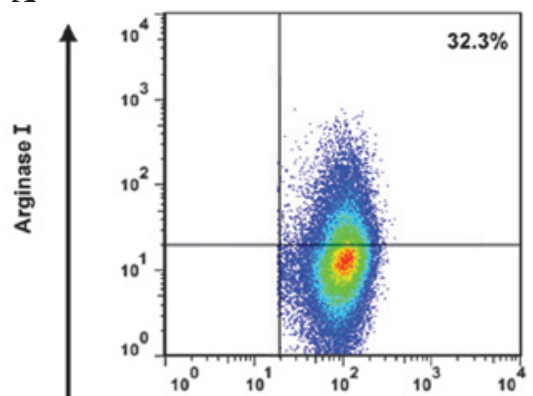

B

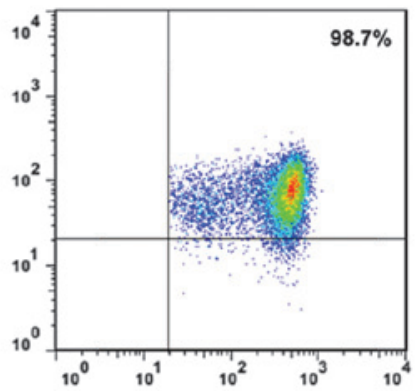

C

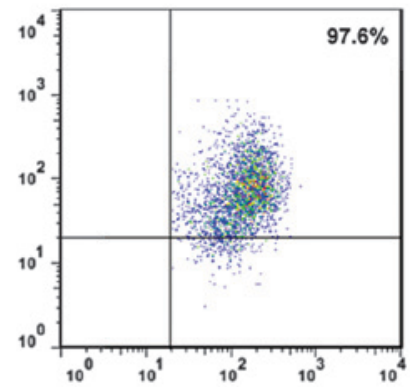

CD4+(CD3+CD8-)

D

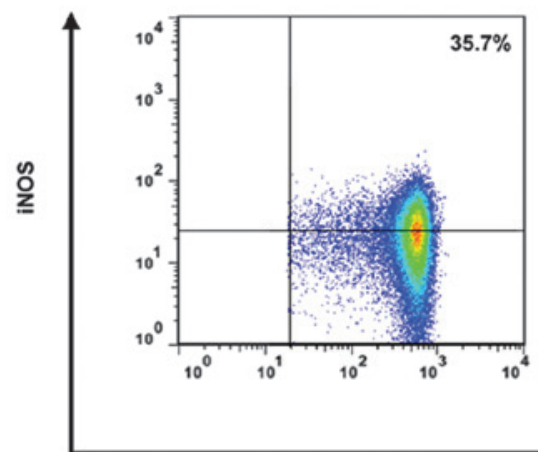

$\mathbf{E}$

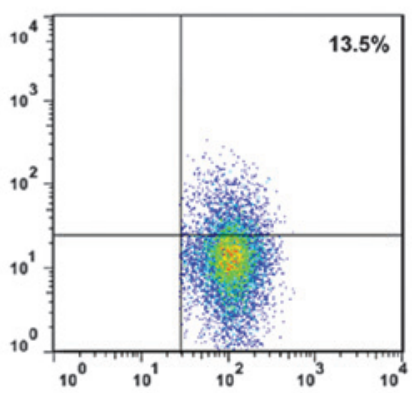

F

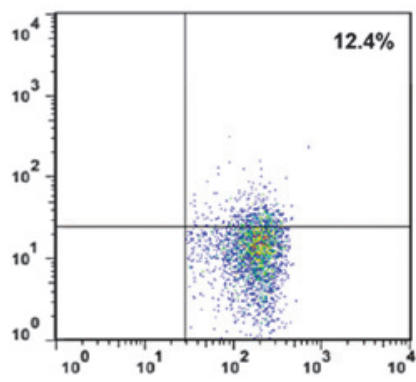

CD4+(CD3+CD8-)
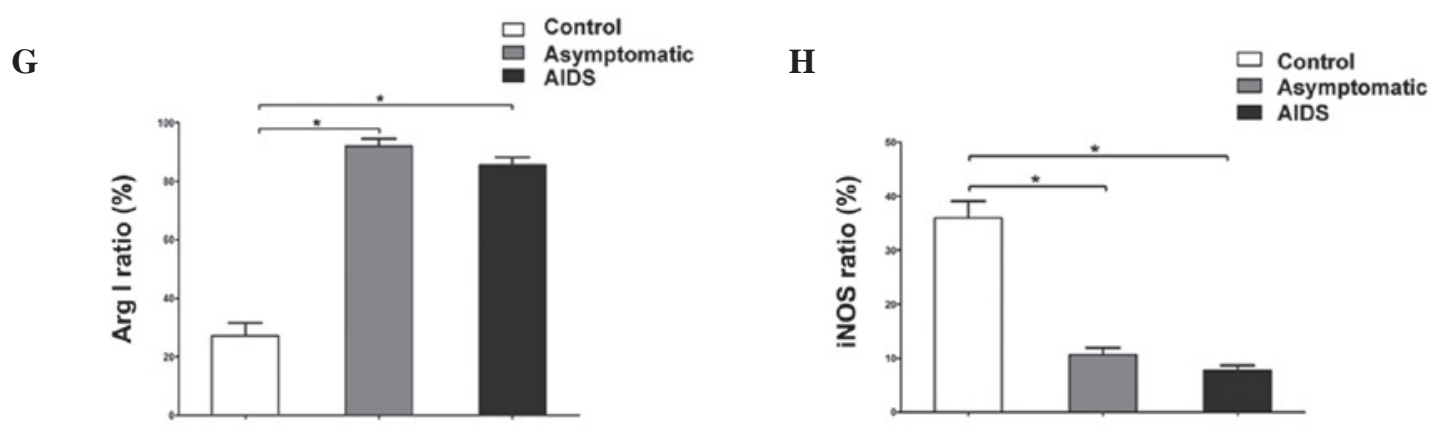

Figure 4. Flow cytometric analysis of the frequencies of $\mathrm{CD} 4{ }^{+} \mathrm{T}$ cells positive for Arg I and iNOS in peripheral LNs. Compared with the (A) control group, the (B) asymptomatic group and (C) symptomatic AIDS group had a significantly higher frequencies of peripheral CD4 ${ }^{+} \mathrm{T}$ cells positive for Arg I. Compared with the (D) control, the (E) asymptomatic group and (F) symptomatic AIDS group had a significantly lower frequencies of peripheral CD4 ${ }^{+} \mathrm{T}$ cells positive for iNOS. Numbers represent the percentages of cells in the indicated boxes. $(\mathrm{G}$ and $\mathrm{H})$ Frequencies of $\mathrm{CD}^{+} \mathrm{T}$ cells positive for Arg I and iNOS in the peripheral superficial LNs. Values are expressed as the mean standard \pm deviation from at least three experiments. " $\mathrm{P}<0.05$. Arg, arginase; iNOS, inducible nitric oxide synthase; LN, lymph node; AIDS, acquired immune deficiency syndrome.

For example, certain cancer cells and pathogens, including Helicobacter pylori and Toxoplasma gondii, may use arginine to induce inflammation-associated immune suppression, leading to immune evasion $(12,31,32,39)$. In the NOS pathway, L-arginine is metabolized by iNOS into citrulline and NO, and NO is important in the destruction of cancer cells, viruses, bacteria and parasites and in regulation of a variety of immune cells (40). NOS has three isoforms, which include two constitutive isoforms, neural NOS and endothelial NOS, and one inducible isoform (iNOS) (41). Constitutive NOS is predominantly involved in the physiological synthesis of NO and the regulation of different physiological functions, and its activity is $\mathrm{Ca} 2^{+}$-dependent (42). However, iNOS is predominantly involved in the immune regulation and pro-inflammatory response $(43,44)$.

L-arginine is a substrate of Arg and iNOS, therefore, high expression levels of Arg may deplete L-arginine and increase levels of ornithine and polyamines, which are required for the proliferation of cells and parasites. A reduction in L-arginine causes a decrease in NO through the iNOS pathway (11). The competition between Arg and iNOS is pivotal in the immune response to infection and determines the course of 
A

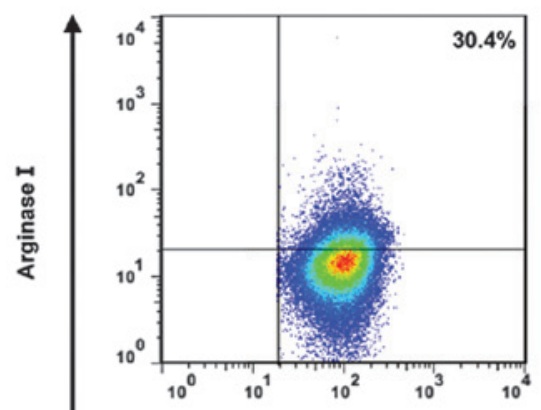

B

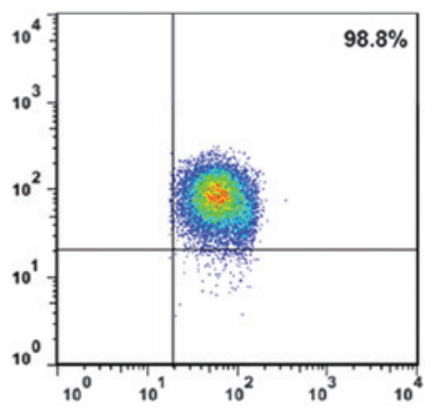

C

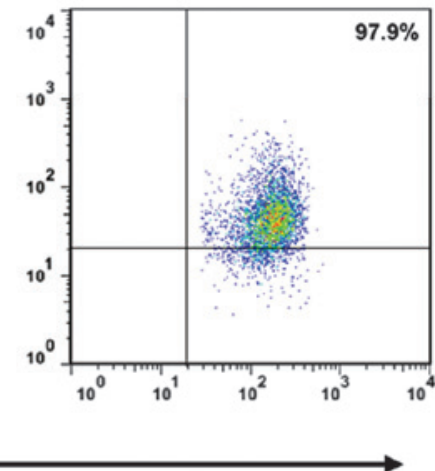

$\mathrm{CD} 8+(\mathrm{CD} 3+\mathrm{CD} 8+)$

D

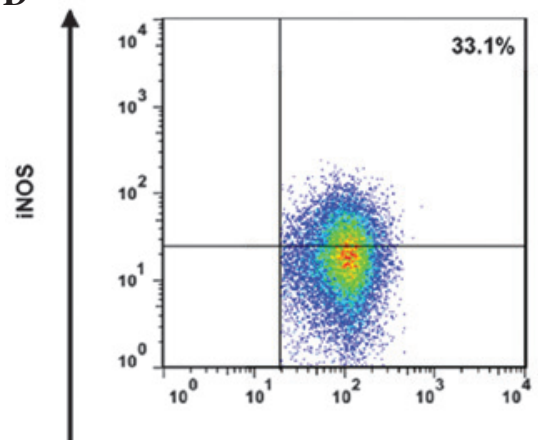

$\mathbf{E}$

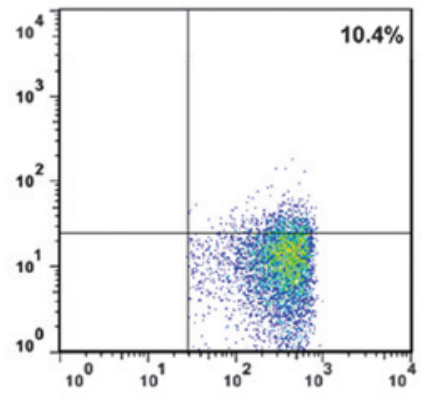

$\mathbf{F}$

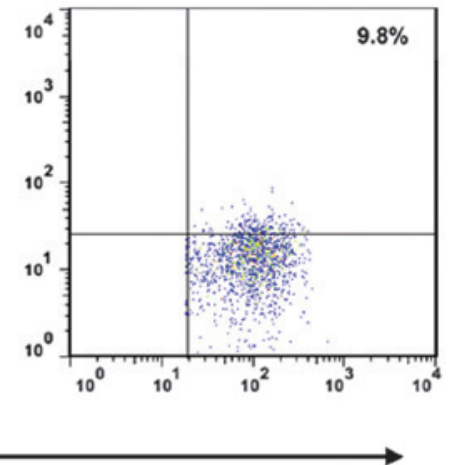

CD8+(CD3+CD8+)

G

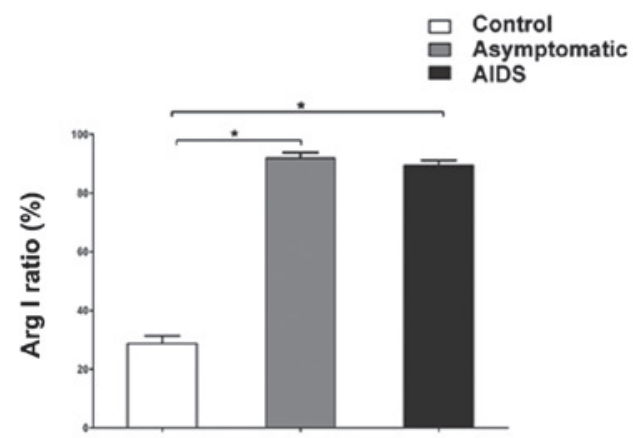

H

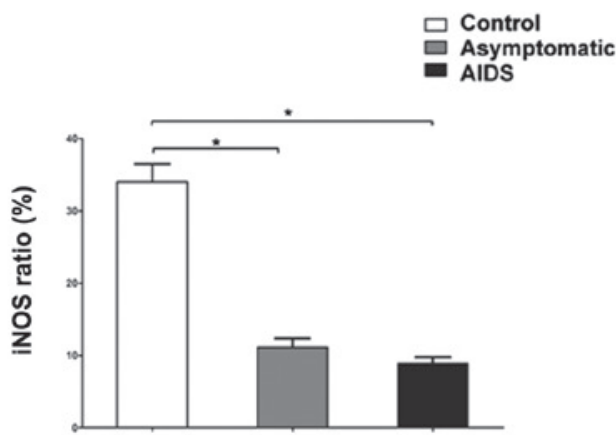

Figure 5. Flow cytometric analysis of the frequencies of CD8 ${ }^{+} \mathrm{T}$ cells positive for Arg I and iNOS in peripheral LNs. Compared with the (A) control group, the (B) asymptomatic group and (C) symptomatic AIDS group had a significantly higher frequency of peripheral CD ${ }^{+} \mathrm{T}$ cells positive for Arg I, Compared with the (D) control, the (E) asymptomatic group and (F) symptomatic AIDS group had a significantly lower frequency of peripheral CD $8^{+} \mathrm{T}$ cells positive for iNOS. Numbers represent the percentages of cells in the indicated boxes. $(\mathrm{G}$ and $\mathrm{H})$ Frequencies of $\mathrm{CD} 8^{+} \mathrm{T}$ cells positive for Arg I and iNOS in the superficial LNs. Values are expressed as the mean standard \pm deviation from at least three experiments. " $\mathrm{P}<0.05$. Arg, arginase; iNOS, inducible nitric oxide synthase; LN, lymph node; AIDS, acquired immune deficiency syndrome.

infection. For example, the peritoneal macrophages in rats differ from those in mice by being resistant to Toxoplasma gondi infection in nature. This resistance has been ascribed to the increased expression and activity of iNOS and, reduced activity of Arg I in rat peritoneal macrophages, compared with mouse peritoneal macrophages (12). HIV infection significantly reduces the number of $\mathrm{CD} 4^{+} \mathrm{T}$ cells, particularly in the AIDS phase, and as polyamine, which is the metabolic product of L-arginine by Arg, is an essential substrate for cell proliferation, increased Arg I in the peripheral blood and LNs can increase the number of $\mathrm{CD}^{+} \mathrm{T}$ cells following HIV infection (11). The results of the present study indicated the negative correlation between the expression of Arg I in peripheral $\mathrm{T}$ cells and LNs and peripheral CD4 ${ }^{+} \mathrm{T}$ cell count, suggesting that the expression of Arg I increased to compensate for the reduction in $\mathrm{CD} 4^{+} \mathrm{T}$ cells.

However, L-arginine regulates the transcription of iNOS in a concentration-dependent manner (39) and Arg significantly reduces the levels of $\mathrm{L}$-arginine, leading to reduction in iNOS synthesis. Thus, the increase in the expression levels 
A

C

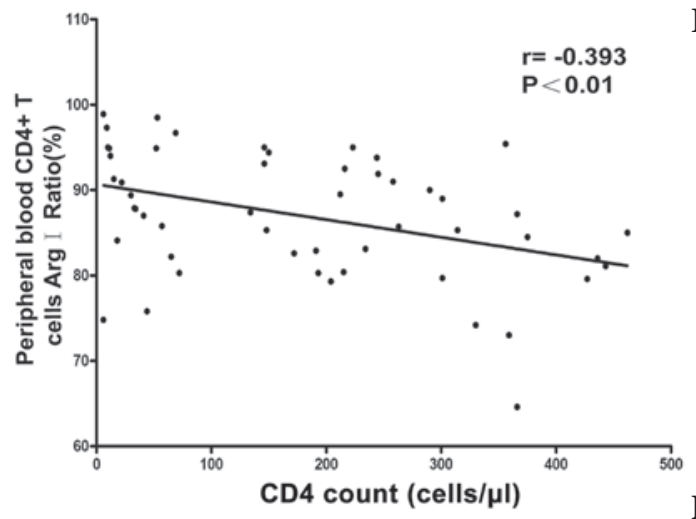

$\mathbf{E}$

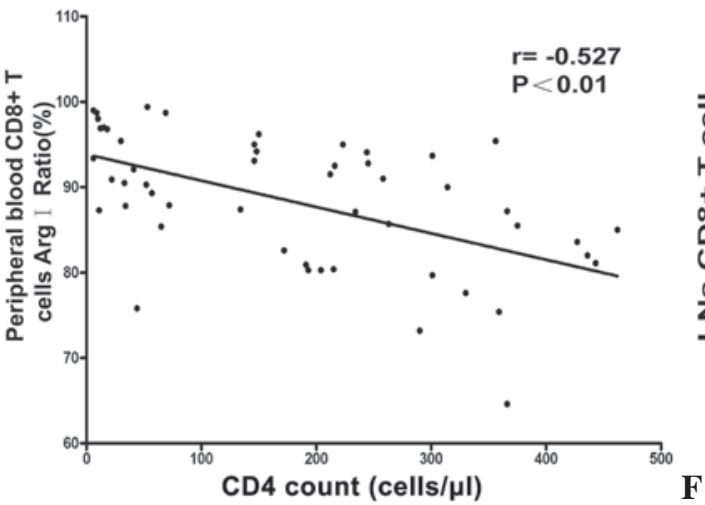

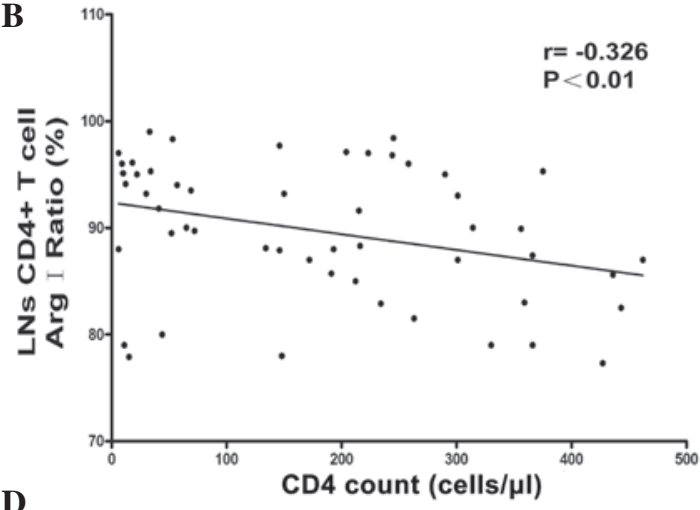
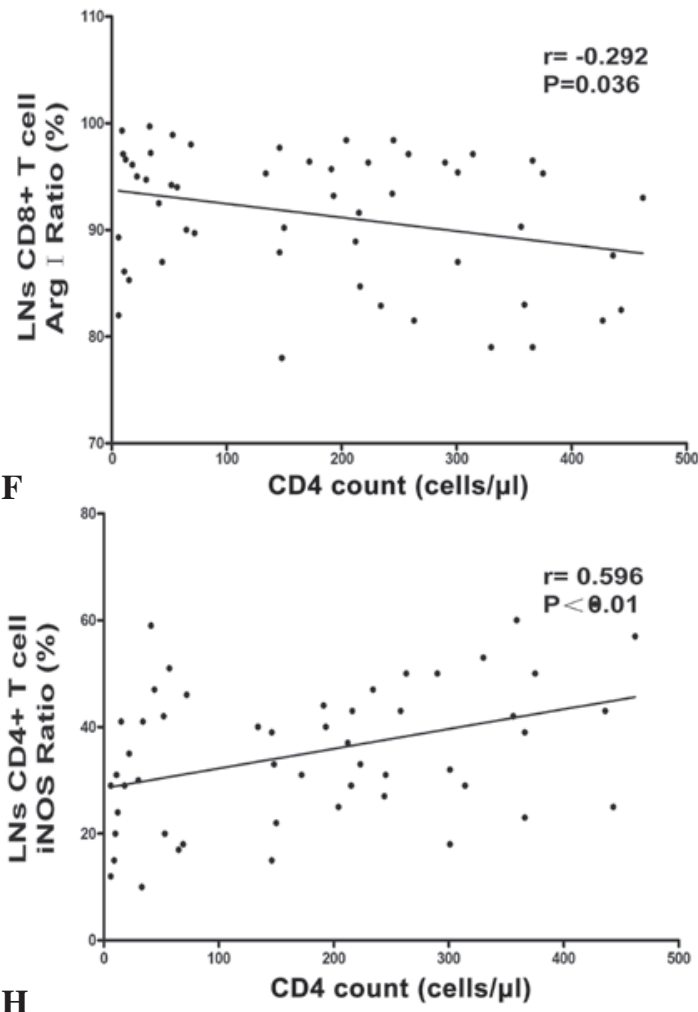

G
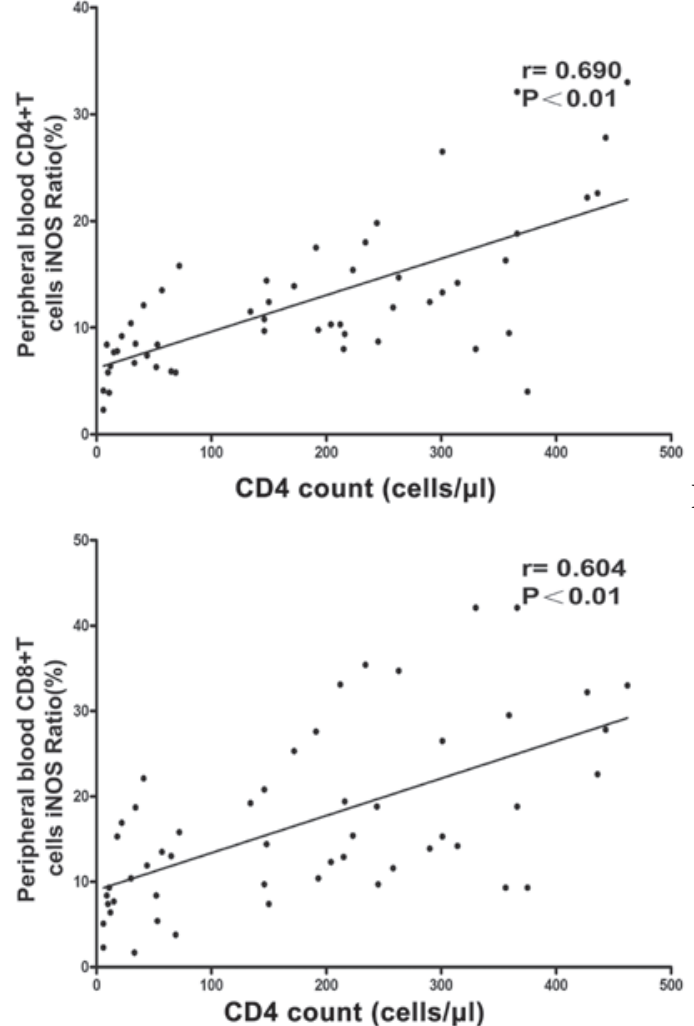

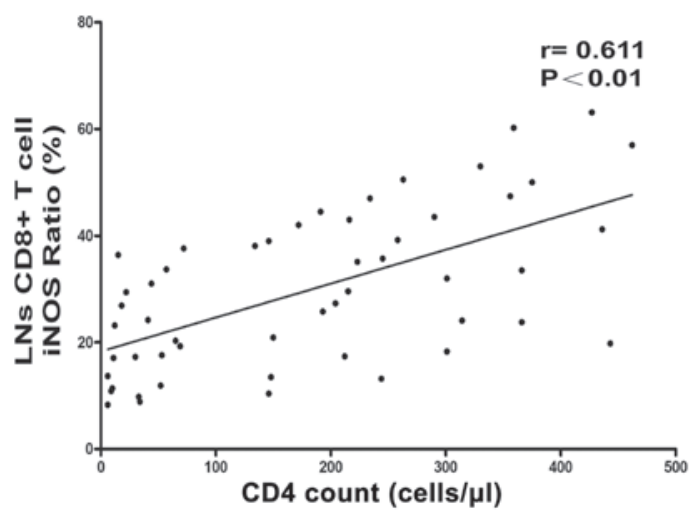

Figure 6. Correlation between the peripheral $\mathrm{CD} 4^{+} \mathrm{T}$ cell count with the frequencies of $\mathrm{CD} 4^{+} \mathrm{T}$ cells and $\mathrm{CD} 8^{+} \mathrm{T}$ cells positive for Arg I and iNOS in the peripheral blood and LNs in patients with human immunodeficiency virus/acquired immune deficiency syndrome.. The peripheral CD $4^{+} \mathrm{T}$ cell count was negatively associated with the frequencies of Arg I positive $\mathrm{CD}^{+} \mathrm{T}$ cells in the (A) peripheral blood and (B) LNs, and the frequencies of Arg I-positive CD8 ${ }^{+}$ $\mathrm{T}$ cells in the (C) peripheral blood and (D) LNs. The peripheral CD4 ${ }^{+} \mathrm{T}$-cell count was positively associated with the frequencies of iNOS-positive CD4 ${ }^{+} \mathrm{T}$ cells in the (E) peripheral blood and (F) LNs, and with the frequencies of iNOS positive CD8 ${ }^{+} \mathrm{T}$ cells in the (G) peripheral blood and (H) LNs. Arg, arginase; iNOS, inducible nitric oxide synthase; LN lymph node.

of Arg I in the peripheral blood and LNs of HIV-infected patients may cause a reduction in the expression of iNOS. This Arg-induced reduction in iNOS synthesis leads to a reduction in the production of $\mathrm{NO}$, and this release of $\mathrm{NO}$ by macrophages is important role in innate immunity (11). The reduced synthesis of NO may directly impair innate 
A

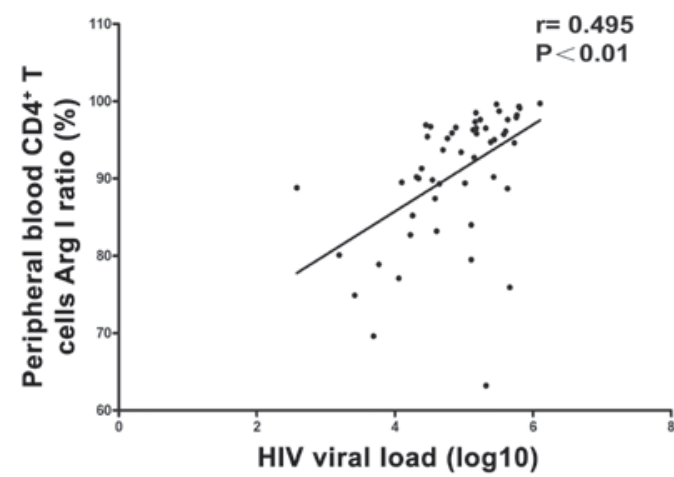

C

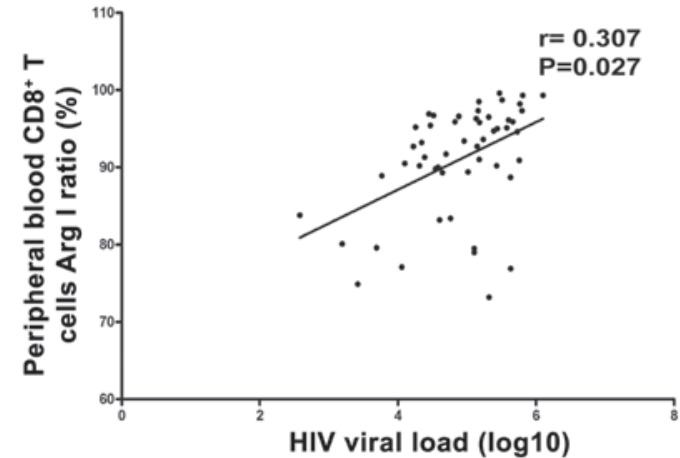

E

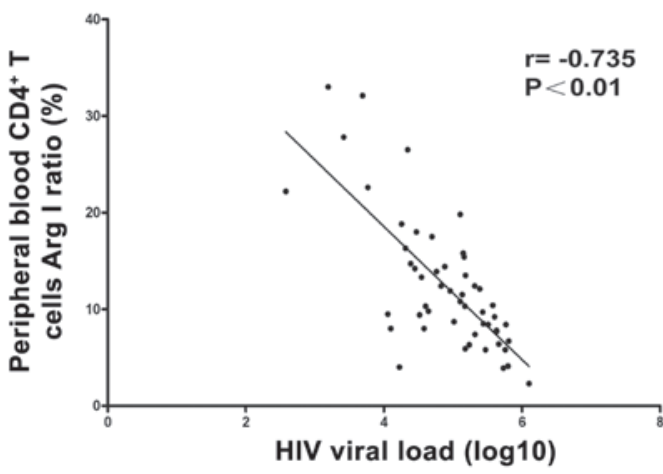

G

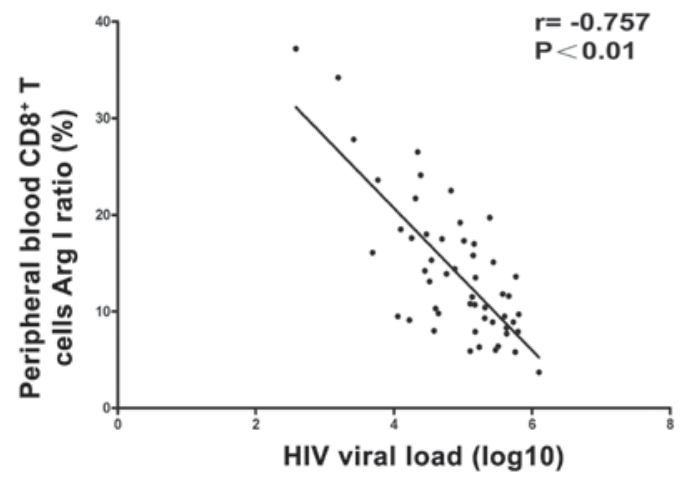

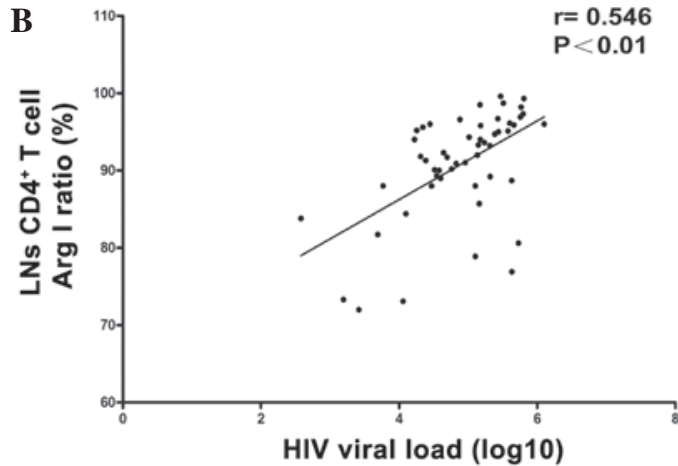

D

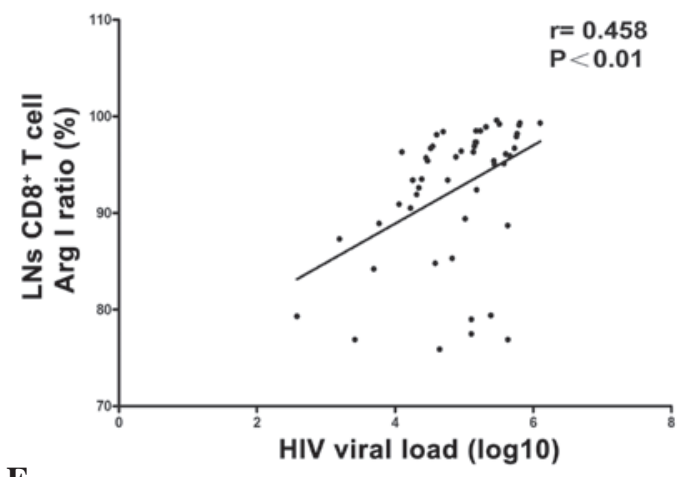

$\mathbf{F}$

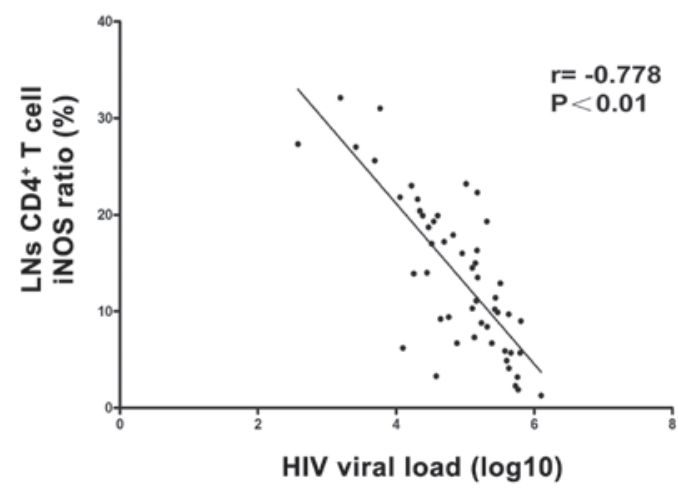

$\mathbf{H}$

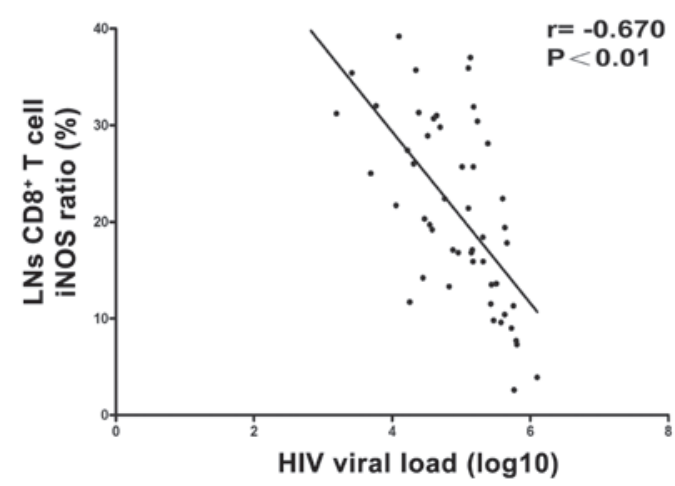

Figure 7. Correlation of viral load with the frequencies of $\mathrm{CD}^{+} \mathrm{T}$ cells and CD8 ${ }^{+} \mathrm{T}$ cells positive for Arg I and iNOS in peripheral blood and LNs in patients with HIV/acquired immune deficiency syndrome. Viral load was positively associated with the frequencies of Arg I positive CD $8^{+} \mathrm{T}$ cells in the (A) peripheral blood and (B) LNs, and with the frequencies of Arg I positive CD8 ${ }^{+}$T cells in the (C) peripheral blood and (D) LNs. Viral load was also negatively associated with the frequencies of iNOS-positive $\mathrm{CD}^{+} \mathrm{T}$ cells in the $(\mathrm{E})$ peripheral blood and $(\mathrm{F}) \mathrm{LNs}$, and with the frequencies of iNOS positive CD ${ }^{+} \mathrm{T}$ cells in the (G) peripheral blood and (H) LNs. HIV, human immunodeficiency virus; Arg, arginase; iNOS, inducible nitric oxide synthase; LN lymph node.

immunity and affect anti-infection ability, increasing immune dysfunction in HIV-infected patients. This may contribute to the increased replication of HIV and reduced anti-infection ability in patients with AIDS, causing opportunistic infections, including pneumocystis pneumonia, tuberculosis, cytomegalovirus and Epstein-Barr virus. Furthermore, the consumption 
A

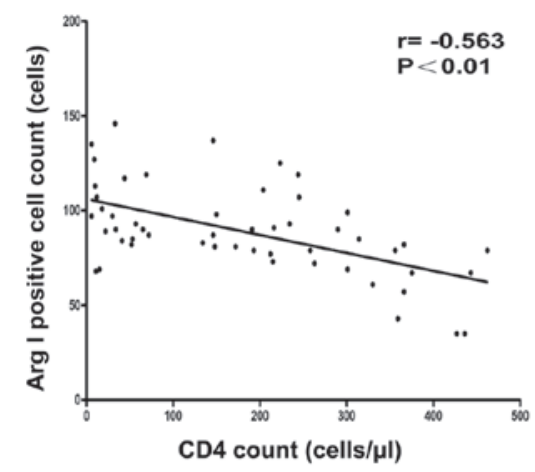

C

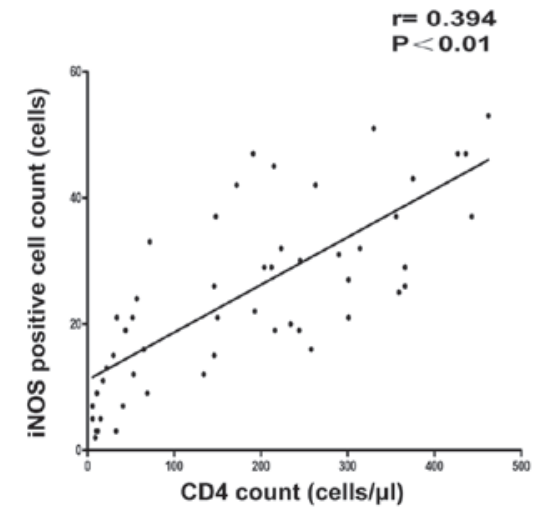

B

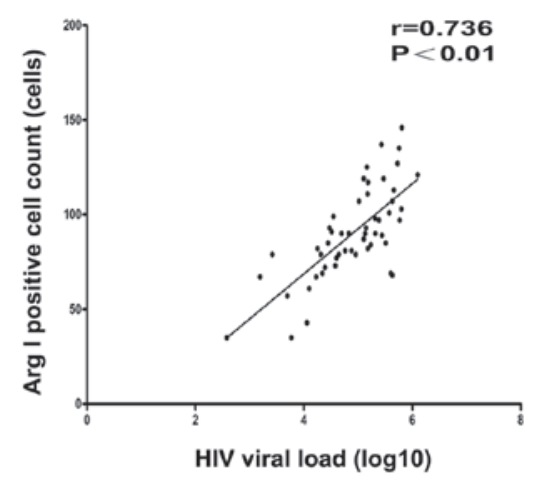

D

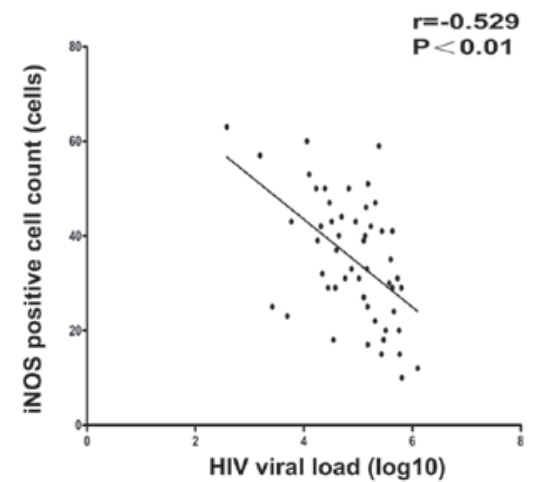

Figure 8. Correlation between the number of Arg I or iNOS positive cells in the superficial LNs, and the CD4 ${ }^{+} \mathrm{T}$ cell count and viral load in patients with HIV/acquired immune deficiency syndrome. (A) Numbers of Arg I positive cells in the peripheral superficial LNs were negatively correlated with the CD4 T cell count. (B) Numbers of iNOS positive cells in the peripheral superficial LNs were positively correlated with CD4 ${ }^{+} \mathrm{T}$ cell count (C) Numbers of Arg I positive cells in the peripheral superficial LNs were positively correlated with HIV load. (D) Numbers of iNOS positive cells in the peripheral superficial LNs were negatively correlated with HIV load, HIV, human immunodeficiency virus; Arg, arginase; iNOS, inducible nitric oxide synthase; LN lymph node.

of L-arginine by Arg causes downregulated expression of the $\mathrm{CD} 3 \zeta$ chain in $\mathrm{CD}^{+} \mathrm{T}$ cells $(6,45,46)$. All these factors contribute to the significant increase in HIV replication and compromise anti-infection ability in the AIDS phase, resulting in the development of opportunistic infections.

The reduction in NO due to the competition between Arg and iNOS is also important in the pathogenesis of a variety of diseases, including atherosclerosis and hypertension, myocardial ischemia/reperfusion injury, diabetes, allergic asthma and inflammatory diseases (47-50). Thus, as an important metabolic enzyme, which affects NO synthesis, mechanisms to inhibit the progression of disease by inhibiting Arg activity and functional interference remains an area of increased interest. Certain synthetic and natural compounds that inhibit Arg have been investigated as disease therapies, with certain small molecule inhibitors of Arg showing potential in the treatment of diabetes, allergic inflammation and Schistosoma mansoni parasitic infection $(47,51,52)$. At the same time, evidence in rats shows that Arg I may serve as a biomarker for the diagnosis of type 2 diabetes (53). The results of the present study also showed that HIV load and peripheral $\mathrm{CD}^{+}{ }^{+} \mathrm{T}$ cells were independently associated with the expression levels of Arg I and iNOS. Thus, although HAART may exert therapeutic effects by reducing the expression of Arg I and increasing the expression of iNOS, Arg inhibitors may be used as an adjuvant therapy to treat HIV infection, particularly in those with AIDS, and to improve immune function, prevent opportunistic infections and inhibit viral replication. In addition, this correlation suggests that the expression levels of Arg I and iNOS in peripheral T cells may be used diagnostically to predict the progression of HIV infections.

In conclusion, the present study suggested that abnormalities in the expression levels of Arg I and iNOS in peripheral blood and LN T cells may be a contributor to compromised immunity in patients with HIV, which are responsible for the significant elevations in viral load during the AIDS phase and the appearance of opportunistic infections. In addition, the expression levels of Arg I and iNOS in the T cells of peripheral blood and LNs may be as a potential parameter to predict disease progression, as the expression levels of Arg I and iNOS in peripheral blood and LN T cells were found to be correlated with HIV load and $\mathrm{CD}^{+}{ }^{+} \mathrm{T}$ cell count.

\section{Acknowledgements}

The present study was supported by grants from the National Natural Science Foundation of China (grant nos. 81072423 81200303 and 81470097), the 12th Five-Year Research Project of People's Liberation Army (grant no. CWS11J160) and the Scientific Research, Technological Development Program and Innovation Project of Nanning (grant no. 20100304C-1).

\section{References}

1. Chen Q, Li Y, Su X, Hao M, Lu H and He X: Epidemiological analysis on recent infected HIV-1 patients among newly reported HIV cases in Beijing, from 2009 to 2011. Zhonghua Liu Xing Bing Xue Za Zhi 35: 53-56, 2014 (In Chinese). 
2. Deeks SG: HIV: How to escape treatment. Nature 477: 36-37, 2011.

3. Lloyd A: HIV infection and AIDS. P N G Med J 39: 174-180, 1996.

4. Hazenberg MD, Otto SA, van Benthem BH, Roos MT, Coutinho RA, Lange JM, Hamann D, Prins M and Miedema F: Persistent immune activation in HIV-1 infection is associated with progression to AIDS. AIDS 17: 1881-1888, 2003.

5. Munder M: Arginase: An emerging key player in the mammalian immune system. Br J Pharmacol 158: 638-651, 2009.

6. Abebe T, Takele Y, Weldegebreal T, Cloke T, Closs E, Corset C, Hailu A, Hailu W, Sisay Y, Corware K, et al: Arginase activity a marker of disease status in patients with visceral leishmaniasis in ethiopia. PLoS Negl Trop Dis 7: e2134, 2013.

7. Nieves CJ Jr and Langkamp-Henken B: Arginine and immunity: A unique perspective. Biomed Pharmacother 56: 471-482, 2002

8. Pavanelli WR, Gutierrez FR, Silva JJ, Costa IC, Menezes MC, Oliveira FJ, Itano EN and Watanabe MA: The effects of nitric oxide on the immune response during giardiasis. Braz J Infect Dis 14: 606-612, 2010.

9. Herrera-Ortiz A, Martinez-Barnetche J, Smit N, Rodriguez MH and Lanz-Mendoza H: The effect of nitric oxide and hydrogen peroxide in the activation of the systemic immune response of Anopheles albimanus infected with Plasmodium berghei. Dev Comp Immunol 35: 44-50, 2011.

10. Zimmermann $\mathrm{N}$ and Rothenberg ME: The arginine-arginase balance in asthma and lung inflammation. Eur J Pharmacol 533 253-262, 2006

11. Peranzoni E, Marigo I, Dolcetti L, Ugel S, Sonda N, Taschin E, Mantelli B, Bronte V and ZanovelloP: Role of arginine metabolism in immunity and immunopathology. Immunobiology 212 795-812, 2007

12. Li Z, Zhao ZJ, Zhu XQ, Ren QS, Nie FF, Gao JM, Gao XJ, Yang TB, Zhou WL, Shen JL, et al: Differences in iNOS and arginase expression and activity in the macrophages of rats are responsible for the resistance against $T$. gondii infection. PLoS One 7: e35834, 2012.

13. Radi R: Nitric oxide, oxidants and protein tyrosine nitration. Proc Natl Acad Sci USA 101: 4003-4008, 2004

14. Hillyer JF and Estévez-Lao TY: Nitric oxide is an essential component of the hemocyte-mediated mosquito immune response against bacteria. Dev Comp Immunol 34: 141-149, 2010

15. Jung K, Gurnani A, Renukaradhya GJ and Saif LJ: Nitric oxide is elicited and inhibits viral replication in pigs infected with porcine respiratory coronavirus but not porcine reproductive and respiratory syndrome virus. Vet Immunol Immunopathol 136 : 335-339, 2010

16. Cloke T, Munder M, Bergin P, Herath S, Modolell M, Taylor G, Müller I and Kropf P: Phenotypic alteration of neutrophils in the blood of HIV seropositive patients. PLoS One 8: e72034, 2013.

17. Cloke TE, Garvey L, Choi BS, Abebe T, Hailu A, Hancock M, Kadolsky U, Bangham CR, Munder M, Müller I, et al: Increased level of arginase activity correlates with disease severity in HIV-seropositive patients. J Infect Dis 202: 374-385, 2010.

18. Cairoli E, Scott-Algara D, Pritsch O, Dighiero G and Cayota A HIV-1 induced decrease of nitric oxide production and inducible nitric oxide synthase expression during in vivo and in vitro infection. Clin Immunol 127: 26-33, 2008.

19. Panel on Antiretroviral Guidelines for Adults and Adolescents. Guidelines for the use of antiretroviral agents in HIV-1-infected adults and adolescents. Department of Health and Human Services. http://www.aidsinfo.nih. gov/ContentFiles/Adultand AdolescentGL.pdf. Accessed November 9, 2015

20. Tassone G and Fidler SJ: Separation and cryopreservation of lymphocytes from spleen and lymph node. Methods Mol Biol 882: 351-357, 2012

21. Singh U and Owen JJ: Studies on subpopulations of foetal thymocytes separated on ficoll hypaque density gradients. Dev Comp Immunol 3: 543-556, 1979.

22. Matos LL, Stabenow E, Tavares MR, Ferraz AR, Capelozzi VL and Pinhal MA: Immunohistochemistry quantification by a digital computer-assisted method compared to semiquantitative analysis. Clinics (Sao Paulo) 61: 417-424, 2006

23. Koot M, Keet IP, Vos AH, de Goede RE, Roos MT, Coutinho RA, Miedema F, Schellekens PT and Tersmette M: Prognostic value of HIV-1 syncytium-inducing phenotype for rate of CD4+ cell depletion and progression to AIDS. Ann Intern Med 118: 681-688, 1993
24. da Costa CM, de Freitas MR, Brazão V, dos Santos CD, Sala MA, do Prado Júnior JC and Abrahão AA: Does L-arginine availability during the early pregnancy alters the immune response of Trypanosoma cruzi infected and pregnant Wistar rats? Exp Parasitol 142: 59-66, 2014.

25. Willard-Mack CL: Normal structure, function, and histology of lymph nodes. Toxico Pathol 34: 409-424, 2006.

26. Gökmen SS, Aygit AC, Ayhan MS, Yorulmaz F and Gülen S: Significance of arginase and ornithine in malignant tumors of the human skin. J Lab Clin Med 137: 340-344, 2001

27. Raber P, Ochoa AC and Rodriguez PC: Metabolism of L-arginine by myeloid-derived suppressor cells in cancer: Mechanisms of $\mathrm{T}$ cell suppression and therapeutic perspectives. Immunol Invest 41: 614-634, 2012.

28. Bansal V and Ochoa JB: Arginine availability, arginase and the immune response. Curr Opin Clin Nutr Metab Care 6: 223-228, 2003.

29. Ash DE, Cox JD and Christianson DW: Arginase: A binuclear manganese metalloenzyme. Met Ions Biol Sys 37: 407-428, 2000.

30. Jenkinson CP, Grody WW and Cederbaum SD: Comparative properties of arginases. Comp Biochem Physiol B Biochem Mol Biol 114: 107-132, 1996.

31. Wijnands KA, Hoeksema MA, Meesters DM, van den Akker NM, Molin DG, Briedé JJ, Ghosh M, Köhler SE, van Zandvoort MA, de Winther MP, et al: Arginase-1 deficiency regulates arginine concentrations and NOS2-mediated NO production during endotoxemia. PLoS One 9: e86135, 2014.

32. Takele Y, Abebe T, Weldegebreal T, Hailu A, Hailu W, Hurissa Z, Ali J, Diro E, Sisay Y, Cloke T, et al: Arginase activity in the blood of patients with visceral leishmaniasis and HIV infection. PLoS Negl Trop Dis 7: e1977, 2013.

33. McLarren KW, Cole AE, Weisser SB, Voglmaier NS, Conlin VS, Jacobson K, Popescu O, Boucher JL and Sly LM: SHIP-deficient mice develop spontaneous intestinal inflammation and arginase-dependent fibrosis. Am J Pathol 179: 180-188, 2011

34. Endo M, Oyadomari S, Terasaki Y, Takeya M, Suga M, Mori M and Gotoh T: Induction of arginase I and II in bleomycin-induced fibrosis of mouse lung. Am J Physiol Lung Cell Mol Physiol 285: L313-L321, 2013.

35. Barron L, Smith AM, El Kasmi KC, Qualls JE, Huang X, Cheever A, Borthwick LA, Wilson MS, Murray PJ and Wynn TA: Role of arginase 1 from myeloid cells in th2-dominated lung inflammation. PLoS One 8: e61961, 2013.

36. Bronte V and Zanovello P: Regulation of immune responses by L-arginine metabolism. Nat Rev Immunol 5: 641-654, 2005.

37. Érsek B, Molnár V, Balogh A, Matkó J, Cope AP, Buzás EI, Falus A and Nagy G: CD3 $\zeta$-chain expression of human T lymphocytes is regulated by TNF via Src-like adaptor protein-dependent proteasomal degradation. J Immunol 189: 1602-1610, 2012.

38. Rodriguez PC, Quiceno DG and Ochoa AC: L-arginine availability regulates T-lymphocyte cell-cycle progression. Blood 109: 1568-1573, 2007.

39. Chaturvedi R, Asim M, Lewis ND, Algood HM, Cover TL, Kim PY and Wilson KT: L-arginine availability regulates inducible nitric oxide synthase-dependent host defense against Helicobacter pylori. Infect Immun 75: 4305-4315, 2007.

40. Wink DA, Hines HB, Cheng RY, Switzer CH, Flores-Santana W, Vitek MP, Ridnour LA and Colton CA: Nitric oxide and redox mechanisms in the immune response. J Leukoc Biol 89: 873-891, 2011.

41. Bogdan C: Nitric oxide and the immune response. Nat Immunol 2: 907-916, 2001.

42. Griffith OW and Stuehr DJ: Nitric oxide synthases: properties and catalytic mechanism. Annu Rev Physiol 57: 707-736, 1995.

43. Wu JX, Zhu HW, Chen X, Wei JL, Zhang XF and Xu MY: Inducible nitric oxide synthase inhibition reverses pulmonary arterial dysfunction in lung transplantation. Inflamm Res 63: 609-618, 2014.

44. Buttery LD, Springall DR, Chester AH, Evans TJ, Standfield EN, Parums DV, Yacoub MH and Polak JM: Inducible nitric oxide synthase is present within human atherosclerotic lesions and promotes the formation and activity of peroxynitrite. Lab Inves 75: 77-85, 1996.

45. Bronte V, Serafini P, Mazzoni A, Segal DM and Zanovello P: L-arginine metabolism in myeloid cells controls T-lymphocyte functions. Trends Immunol 24: 302-306, 2003.

46. Popovic PJ, Zeh HJ III and Ochoa JB. Arginine and immunity. J Nutr 137 (6 Suppl 2): S1681-S1686, 2007.

47. Steppan J, Nyhan D and Berkowitz DE. Development of novel arginase inhibitors for therapy of endothelial dysfunction. Front Immunol 4: 278, 2013 
48. Jung C, Quitter F, Lichtenauer M, Fritzenwanger M, Pfeil A, Shemyakin A, Franz M, Figulla HR, Pfeifer R and Pernow J: Increased arginase levels contribute to impaired perfusion after cardiopulmonary resuscitation. Eur J Clin Invest 44: 965-971, 2014.

49. Maarsingh H, Dekkers BG, Zuidhof AB, Bos IS, Menzen MH, Klein T, Flik G, Zaagsma J and Meurs H: Increased arginase activity contributes to airway remodelling in chronic allergic asthma. Eur Respir J 38: 318-328, 2011

50. Horowitz S, Binion DG, Nelson VM, Kanaa Y, Javadi P, Lazarova Z, Andrekopoulos C, Kalyanaraman B, Otterson MF and Rafiee P: Increased arginase activity and endothelial dysfunction in human inflammatory bowel disease. Am J Physiol Gastrointest Liver Physiol 292: G1323-G1336, 2007.
51. Kovamees O, Shemyakin A and Pernow J: Effect of arginase inhibition on ischemia-reperfusion injury in patients with coronary artery disease with and without diabetes mellitus. PLoS One 9: e103260, 2014

52. Hai Y, Edwards JE, Van Zandt MC, Hoffmann KF and Christianson DW: Crystal structure of Schistosoma mansoni arginase, a potential drug target for the treatment of schistosomiasis. Biochemistry 53: 4671-4684, 2014.

53. Wang S, Fang F, Jin WB, Wang X and Zheng DW: Assessment of serum arginase $\mathrm{I}$ as a type 2 diabetes mellitus diagnosis biomarker in patients. Exp Ther Med 8: 585-590, 2014. 